\title{
ANALISIS RESPON HIDROLOGI TERHADAP PENERAPAN TEKNIK KONSERVASI TANAH DI SUB DAS LENGKONG MENGGUNAKAN MODEL SWAT
}

\section{Hydrological Response Analysis for the Application of Soil Conservation Techniques in Sub-watershed Lengkong Using SWAT Model}

\author{
Gunadi Firdaus1)*, Oteng Haridjaja2), dan Suria Darma Tarigan²) \\ 1) Alumni Program Studi Ilmu Pengelolaan Daerah Aliran Sungai, Sekolah Pascasarjana IPB, Jl. Raya Darmaga, \\ Gedung Andi Hakim Nasoetion Kampus IPB Darmaga Bogor 16680 \\ 2) Departemen Ilmu Tanah dan Sumberdaya Lahan Fakultas Pertanian IPB, Jln. Meranti Kampus IPB Dramaga \\ Bogor 16680
}

\begin{abstract}
One cause of flooding and erosion is the biophysical conditions of the upstream watershed that can not support the hydrological function of the watershed. It is necessary to implement appropriate measures of soil conservation techniques to improve the hydrological functions of the watershed. This research aims to: (1) analyze the hydrological response based on biophysical condition of the watershed on a meso-scale level, and (2) analyze the hydrological response based on soil conservation practices scenario application. The study area located in Lengkong watershed in the upper Cisadane basin covering an area of 1,788 ha. This research was carried out using Soil and Water Assessment Tool (SWAT) hydrological modeling. Hydrological response analysis resulted from soil conservation scenario application showed that the ratio of Qmax and Qmin value of 149.71 for scenario 1 (strip cropping) and 2 (contour cropping), 149.80 for scenario 3 (terracing), 150.25 for scenario 4 (combine scenario 1 and 2), and 149.31 for scenario 5 (combine scenario 1, 2 and 3) respectively. Based on the potential erosion ratio with tolerable erosion, an erosion hazard index of 2.63 (moderate) for scenario 1; 2.57 (moderate) for scenario 2; 0.60 (low) for scenario 3; 2.45 (moderate) for scenario 4; and 0.44 (low) for scenario 5 . Application of soil conservation techniques that combine the contour cropping and strip cropping with terracing collectively, was the best soil conservation techniques to improve hydrological response of the watershed. This techniques are recommended to be applied especially in Lengkong watershed and generally in the upper of Cisadane basin.
\end{abstract}

Keywords: Flow-out, sediment-yield, soil conservation, SWAT, watershed

\section{ABSTRAK}

Salah satu penyebab banjir dan erosi adalah kondisi biofisik di bagian hulu Daerah Aliran Sungai (DAS) yang sudah tidak dapat mendukung fungsi hidrologis DAS. Perlu dilakukan upaya-upaya penerapan teknik konservasi tanah yang tepat untuk memperbaiki fungsi hidrologis DAS tersebut. Penelitian ini bertujuan untuk: (1) menganalisis respon hidrologi berdasarkan kondisi biofisik DAS pada tingkat analisis skala meso, dan (2) menganalisis respon hidrologi berdasarkan penerapan skenario teknik konservasi tanah. Wilayah kajian untuk penelitian adalah di sub DAS Lengkong yang terletak di bagian hulu DAS Cisadane seluas 1,788 ha. Penelitian ini dilakukan dengan menggunakan pemodelan hidrologi Soil and Water Assessment Tool (SWAT). Hasil analisis respon hidrologi terhadap penerapan skenario konservasi tanah menunjukkan Koefisien Regim Sungai sebesar 149.71 untuk skenario 1 (penanaman tanaman strip) dan 2 (penanaman pohon mengikuti kontur), sebesar 149.80 untuk skenario 3 (pembuatan teras), sebesar 150.25 untuk skenario 4 (gabungan skenario 1 dan 2), dan sebesar 149.31 untuk skenario 5 (gabungan skenario 1, 2 dan 3). Berdasarkan nisbah erosi potensial dengan erosi yang dapat ditoleransi, diperoleh indeks bahaya erosi untuk skenario 1 sebesar 2.63 (sedang), skenario 2 sebesar 2.57 (sedang), skenario 3 sebesar 0.60 (rendah), skenario 4 sebesar 2.45 (sedang), dan skenario 5 sebesar 0.44 (rendah). Penerapan teknik konservasi tanah yang mengkombinasikan penanaman pohon mengikuti kontur dan penanaman tanaman strip dengan pembuatan teras secara bersamaan, merupakan teknik konservasi tanah yang terbaik untuk memperbaiki respon hidrologi DAS, sehingga dapat direkomendasikan untuk diterapkan di sub DAS Lengkong pada khususnya, dan di DAS Cisadane bagian hulu pada umumnya.

Kata kunci: Debit, sedimen, konservasi tanah, SWAT, DAS

\section{PENDAHULUAN}

DAS Cisadane termasuk dalam DAS Prioritas Nasional (Kemenhut, 2009). Hasil review lahan kritis yang dilakukan oleh Kementerian Kehutanan melalui Balai Pengelolaan Daerah Aliran Sungai (BPDAS) Citarum-
Ciliwung pada tahun 2009 menunjukkan bahwa luas lahan kritis di DAS Cisadane adalah 55,685 ha atau mencapai $36 \%$ dari luas total DAS Cisadane 154,654 ha. Sampai dengan akhir tahun 2012, penanganan lahan kritis di DAS Cisadane tidak banyak dilakukan, sehingga luasnya tidak berkurang, malah cenderung bertambah seiring dengan 
berlangsungnya gangguan dan kerusakan yang dilakukan oleh berbagai aktivitas manusia terutama di bagian hulu DAS. Tercatat jumlah erosi di Cisadane bagian hulu seluas 42,837 ha pada tahun 2011 adalah sebesar 6.2 juta ton tahun $^{-1}$ dengan laju erosi mencapai 144.78 ton $^{-1} a^{-1}$ tahun $^{-1}$ (BPDAS Citarum-Ciliwung, 2012).

Dalam fokus wilayah yang lebih sempit, salah satu Sub DAS Cisadane yang berada di bagian hulu DAS yaitu Sub DAS Lengkong dengan luas 1,778 ha atau sekitar $4 \%$ dari luas DAS Cisadane bagian hulu, mempunyai laju erosi sebesar 165.38 ton ha ${ }^{-1} \operatorname{tahun}^{-1}$ atau 20.6 ton ha ${ }^{-1}$ tahun $^{-1}$ lebih tinggi dari laju erosi DAS Cisadane bagian hulu. Laju erosi yang cukup tinggi di DAS Cisadane bagian hulu pada umumnya dan Sub DAS Lengkong pada khususnya, disebabkan terutama oleh sistem budidaya pertanian lahan kering seperti ladang dan pertanian campuran yang tidak dibarengi dengan penerapan teknik konservasi tanah yang baik dan benar (BPDAS CitarumCiliwung, 2012). Penelitian ini bertujuan untuk menganalisis respon hidrologi berdasarkan kondisi biofisik DAS pada tingkat analisis skala meso, dan menganalisis respon hidrologi berdasarkan penerapan skenario teknik konservasi tanah.

\section{BAHAN DAN METODE}

Penelitian dilakukan di Sub DAS Lengkong yang terletak dibagian hulu DAS Cisadane yang secara administrasi masuk ke dalam Desa Pasirbuncir Kecamatan Caringin Kabupaten Bogor Propinsi Jawa Barat (Gambar 1) seluas 1,788 ha dengan lokasi outlet yang menjadi fokus penelitian terletak pada koordinat $106^{\circ} 49^{\prime} 45.4$ ' Bujur Timur, dan $6^{\circ} 45^{\prime}$ 28.3” Lintang Selatan.

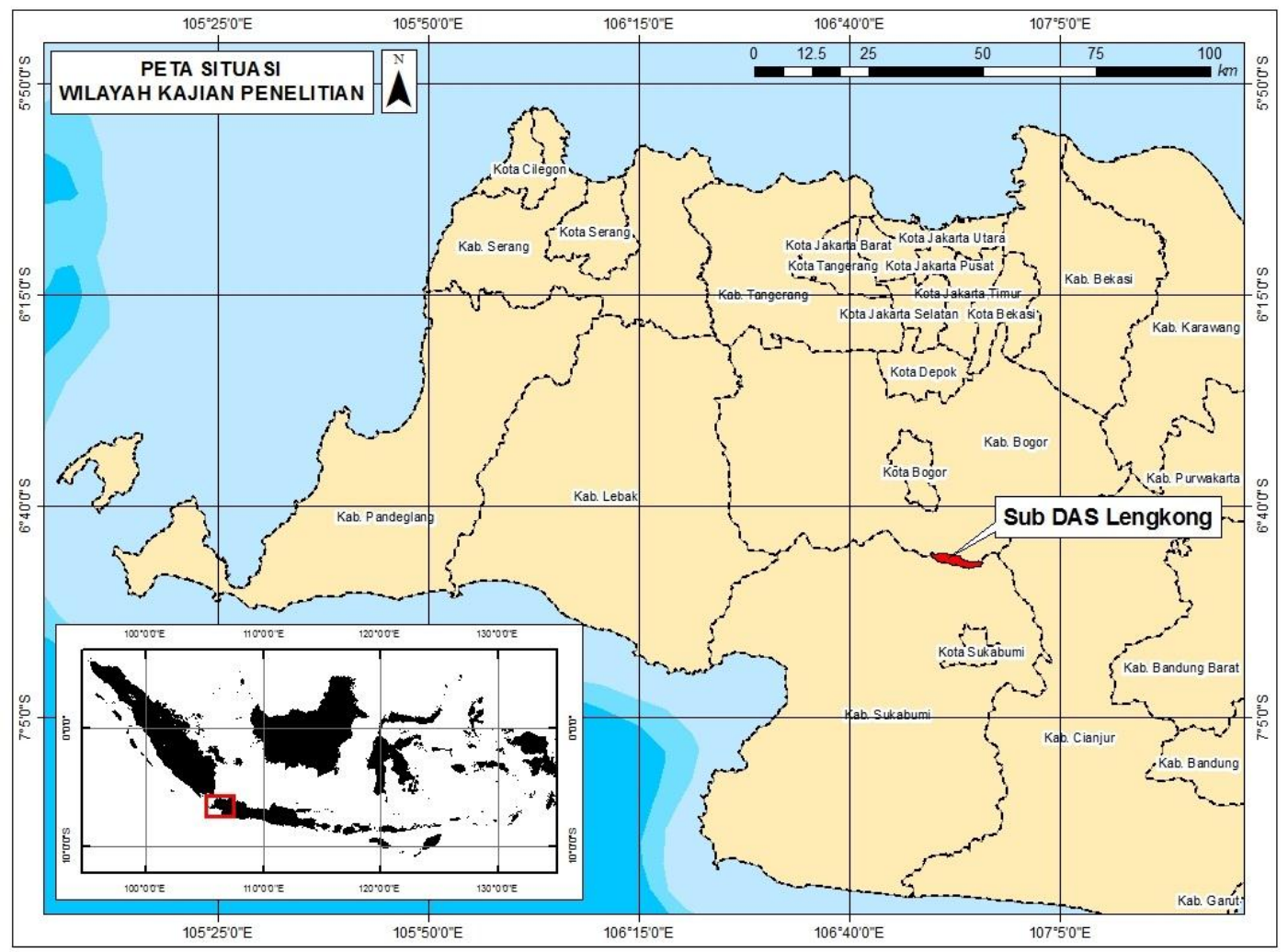

Gambar 1. Peta situasi wilayah penelitian

\section{Bahan}

Data yang digunakan dibagi menjadi dua jenis yaitu data spasial dan data numerik. Data spasial yang digunakan adalah: (1) peta tutupan lahan skala $1: 25,000$ berdasarkan interpretasi citra satelit wordview, (2) peta klasifikasi tanah skala 1 : 100,000 dari Pusat Penelitian Tanah dan Agroklimat (Puslitanak) Bogor, dan (3) Digital Elevation Model (DEM) dari Citra SRTM (Tabel 1). Data spasial digunakan untuk keperluan pembentukan jaringan sungai, pembentukan outlet, batas DAS dan HRU. Data numerik yang digunakan yaitu: (1) data curah hujan harian dan suhu maksimum dan minimum harian selama 3 tahun (2009-2011) didapatkan dari BPDAS Citarum-Ciliwung dan Balai Pengelolaan Sumber Daya Air (BPSDA) Ciliwung-Cisadane, (2) data iklim didapatkan dari Stasiun Badan Meteorologi Klimatologi dan Geofisika (BMKG)
Dramaga yang merupakan hasil pengolahan data cuaca bulanan (curah hujan, suhu udara, kelembaban udara, radiasi surya dan kecepatan angin) selama 10 tahun yaitu tahun 2001 sampai 2010, dan (3) data debit dan sedimen rata-rata harian selama 3 tahun (2009-2011) dari BPDAS Citarum-Ciliwung, yang akan digunakan untuk kalibrasi dan validasi model.

Tabel 1. Kualifikasi data spasial yang digunakan di Sub DAS Lengkong

\begin{tabular}{llll}
\hline Data Spasial & Skala & Sumber & Tahun \\
\hline DEM & $1: 25,000$ & Citra SRTM 30 m & 2013 \\
Tutupan lahan & $1: 25,000$ & Interpretasi citra & 2011 \\
Klasifikasi tanah & $1: 100,000$ & wordview & 1992 \\
& & Puslitanak, Bogor & \\
\hline
\end{tabular}




\section{Alat}

Peralatan yang digunakan dalam penelitian ini adalah seperangkat komputer dengan perangkat lunak ArcGIS 9.3, ArcSWAT versi 2009.93.5 dan Microsoft Office 2010. Untuk perhitungan koefisien deterministik $\left(\mathrm{R}^{2}\right)$ dan efisiensi Nash-Sutcliffe (NS) digunakan perangkat lunak SWATPlot. Untuk perhitungan $\mathrm{R}^{2}$ dengan grafik sebaran seri data secara linier digunakan program MS.excel. Untuk proses kalibrasi dan validasi model digunakan perangkat lunak SWAT-CUP dengan algoritma Sequential Uncertainty Fitting Version 2 (SUFI2).

\section{Analisis Data}

\section{Penetapan HRU dan Menjalankan Model SWAT}

Penetapan Hidrology Respons Unit (HRU) diawali oleh deliniasi batas Sub DAS Lengkong berdasarkan input peta DEM, dengan titik outlet pada koordinat $106^{\circ} 82^{\prime}$ 87.3" bujur timur dan $6^{0} 75^{\prime} 78^{\prime \prime}$ lintang selatan dengan menggunakan model SWAT. HRU dibentuk menggunakan model SWAT dengan cara menggabungkan (overlay) peta tanah, peta liputan lahan, dan peta lereng. HRU yang telah terbentuk digabungkan dengan data-data iklim meliputi data iklim global, data curah hujan harian rata-rata serta data suhu maksimum dan minimum harian rata-rata, kemudian SWAT dijalankan. Model SWAT yang telah dijalankan akan menghasilkan output model diantaranya debit harian rata-rata (FLOW_OUT) dan hasil sedimen (SYLD).

\section{Uji Akurasi Hasil Model, Kalibrasi, dan Validasi}

Output model diuji keakuratannya dengan menggunakan persamaan efisiensi model Nash-Sutcliffe (NS):

$$
N S=1-\frac{\sum_{i=1}^{n}(y-\hat{y})^{2}}{\sum_{i=1}^{n}(y-\bar{y})^{2}}
$$

dimana $\overline{\mathrm{y}}$ adalah variable rata-rata yang terukur $(\mathrm{mm}), \hat{\mathrm{y}}$ adalah variable hasil simulasi ( $\mathrm{mm}$ ), dan y adalah variable terukur. Efisiensi model NS dikelompokkan menjadi tiga kelas (Nash et al., 1970) yaitu baik (NS $\geq 0.75$ ), memuaskan (0.75 > NS > 0.36) dan kurang memuaskan (NS $<0.36)$.

Tabel 2. Parameter input model untuk kalibrasi

\begin{tabular}{|c|c|c|c|}
\hline No. & Parameter & Definisi & Unit \\
\hline 1 & $\mathrm{CN} 2$ & Curve Number in moisture condition II & - \\
\hline 2 & ALPHA_BF & Baseflow alpha factor. & hari \\
\hline 3 & GW_DELAY & Groundwater delay. & hari \\
\hline 4 & GWQMN & $\begin{array}{l}\text { Threshold depth of water in the shallow aquifer required for return flow to } \\
\text { occur. }\end{array}$ & $\mathrm{mm}$ \\
\hline 5 & GW_REVAP & Groundwater "revap" coefficient. & - \\
\hline 6 & ESCO & Soil evaporation compensation factor. & - \\
\hline 7 & CH_N2 & Manning's " $n$ " value for the main channel. & - \\
\hline 8 & $\mathrm{CH}_{-} \_\mathrm{K} 2$ & Effective hydraulic conductivity in main channel alluvium. & $\mathrm{mm} \mathrm{jam}^{-1}$ \\
\hline 9 & ALPHA_BNK & Baseflow alpha factor for bank storage. & - \\
\hline 10 & SOL_AWC & Available water capacity of the soil layer. & $\mathrm{mm} \mathrm{mm}^{-1}$ \\
\hline 11 & SOL_K & Saturated hydraulic conductivity. & $\mathrm{mm} \mathrm{jam}^{-1}$ \\
\hline 12 & SOL_BD & Moist bulk density. & - \\
\hline 13 & RCHRG_DP & Deep aquifer percolation fraction. & - \\
\hline 14 & SURLAG & Surface runoff lag time. & hari \\
\hline 15 & USLE_P & USLE support practice faktor & - \\
\hline 16 & REVAPMN & Threshold depth of water in the shallow aquifer for "revap" to occur. & $\mathrm{mm}$ \\
\hline 17 & GWHT & Initial groundwater height. & $\mathrm{m}$ \\
\hline 18 & SHALLST & Initial depth of water in the shallow aquifer. & $\mathrm{mm}$ \\
\hline 19 & DEEPST & Initial depth of water in the deep aquifer. & $\mathrm{mm}$ \\
\hline 20 & GW_SPYLD & Specific yield of the shallow aquifer. & $\mathrm{m}^{3} \mathrm{~m}^{-3}$ \\
\hline 21 & SOL_ZMX & Maximum rooting depth of soil profile. & $\mathrm{mm}$ \\
\hline 22 & SOL_CRK & Crack volume potential of soil. & $\mathrm{m}^{3} \mathrm{~m}^{-3}$ \\
\hline 23 & SLSUBBSN & Average slope length. & $\mathrm{mm}$ \\
\hline 24 & HRU_SLP & Average slope steepness & $\mathrm{m} \mathrm{m}^{-1}$ \\
\hline 25 & $\mathrm{OV} \_\mathrm{N}$ & Manning's " $n$ " value for overland flow. & - \\
\hline 26 & LAT_TTIME & Lateral flow travel time. & hari \\
\hline 27 & LAT_SED & Sediment concentration in lateral flow and groundwater flow & $\mathrm{mg}^{-1}$ \\
\hline 28 & SLSOIL & Slope length for lateral subsurface flow. & $\mathrm{m}$ \\
\hline
\end{tabular}

Selain itu, untuk melihat keakuratan pola hasil keluaran model dengan hasil observasi lapangan digunakan koefisien deterministik atau persamaan linier:

$$
R^{2}=\frac{(X-\bar{X})^{2}-(X-Y)^{2}}{(X-\bar{X})^{2}}
$$

dimana $X$ adalah besarnya variable pengamatan, $\bar{X}$ adalah variable rata-rata pengamatan dan $Y$ adalah variable perhitungan model. Hasil perhitungan $\mathrm{R}^{2}$ menunjukkan evaluasi kelayakan model tersebut, apabila $\mathrm{R}^{2}$ mendekati 1 maka terdapat hubungan yang erat antara hasil prediksi model dengan hasil observasi lapangan. Apabila hasil 
pengujian $\mathrm{R}^{2}$ dan NS $\quad 0.75$ maka dilakuan kalibrasi menggunakan SWAT-CUP terhadap 28 parameter (Tabel 2) yang dipilih berdasarkan hasil penelitian Mulyana (2012), Latifah (2013) dan Yustika (2013).

Nilai terbaik untuk masing-masing parameter digunakan untuk menggantikan nilai parameter model sebelumnya, kemudian dilakukan validasi dengan cara menjalankan model yang telah terkalibrasi tersebut terhadap tahun yang berbeda. Apabila uji akurasi model hasil validasi mencapai nilai $\mathrm{NS}$ dan $\mathrm{R}^{2} \geq 0.75$ maka model sudah dapat digunakan untuk menjalankan skenario penerapan konservasi tanah.

\section{Skenario Penerapan Konservasi Tanah}

Berdasarkan pada Rencana Pengelolaan Rehabilitasi Hutan dan Lahan (RP-RHL) Kabupaten Bogor Tahun 2011-2015, teknik konservasi tanah yang dijadikan skenario dalam penelitian ini adalah: (1) strip cropping atau penanaman tanaman strip, (2) contour cropping atau penerapan teknik penanaman pohon mengikuti kontur, (3) terracing atau pembuatan teras, (4) kombinasi skenario 1 dan 2, dan (5) kombinasi skenario 1 , 2 dan 3. Semua skenario teknik konservasi tanah itu dilakukan di semua HRU pada kelerengan $<45 \%$ dengan pengecualian tutupan lahan hutan dan pemukiman. Dari lima skenario tersebut, dapat dilihat masing-masing hasilnya dan perbandingan respon hidrologinya berupa Koefisien Regim Sungai (KRS), dan Indek Bahaya Erosi (IBE).

Untuk perhitungan KRS digunakan persamaan:

$$
K R S=\frac{Q m a k}{Q \min }
$$

dimana KRS adalah koefisien regim sungai, Qmak adalah debit rata-rata harian maksimum $\left(\mathrm{m}^{3}\right.$ detik $\left.^{-1}\right)$ dan $Q m i n$ adalah debit rata-rata harian minimum $\left(\mathrm{m}^{3} \operatorname{detik}^{-1}\right)$.
Semakin kecil KRS semakin menunjukkan kondisi DAS dalam keadaan baik (Asdak, 2007).

Untuk perhitungan indeks bahaya erosi digunakan persamaan:

$$
I B E=\frac{E P}{T S L}
$$

dimana $I B E$ adalah indeks bahaya erosi, $E P$ adalah erosi potensial (ton ha $^{-1}$ tahun $^{-1}$ ) dan TSL atau Etol adalah erosi yang dapat ditoleransi (ton $\mathrm{ha}^{-1} \operatorname{tahun}^{-1}$ ). Adapun untuk memperoleh nilai erosi yang masih dapat ditoleransi digunakan persamaan:

$$
\text { Etol }=\frac{D E x f d}{T}
$$

dimana $D E$ adalah kedalaman solum tanah $(\mathrm{mm}), F d$ adalah nilai faktor kedalaman tanah, dan $T$ adalah umur guna sumber daya tanah (tahun). Untuk mendapatkan nilai Etol dalam satuan ton ha ${ }^{-1}$ tahun $^{-1}$ maka nilai Etol dikalikan dengan bobot isi tanah $\left(\mathrm{g} \mathrm{cm}^{-3}\right)$ dikalikan 10 (Arsyad, 2010).

\section{HASIL DAN PEMBAHASAN}

\section{Identifikasi Kondisi Biofisik}

\section{Jenis Tanah}

Hasil klasifikasi tanah (Gambar 2), berdasarkan peta tanah dari Pusat Penelitian Tanah dan Agroklimat (Puslitanak) Bogor skala 1 : 100,000, jenis tanah di sub DAS Lengkong diklasifikasikan menjadi dua yaitu Andic Humitropepts seluas 113 ha $(6 \%)$ yang berada di bagian hilir sub DAS Lengkong dan Typic Hapludands seluas 1 $675(94 \%)$ berada di bagian hulu, tengah dan sedikit di bagian hilir Sub DAS Lengkong. Database peta tanah spasial diberikan tambahan informasi kelompok hidrologi, morfologi, dan sifat-sifat tanah, hasil uji laboratorium 2 sample profil tanah oleh Puslitanak (Tabel 3).

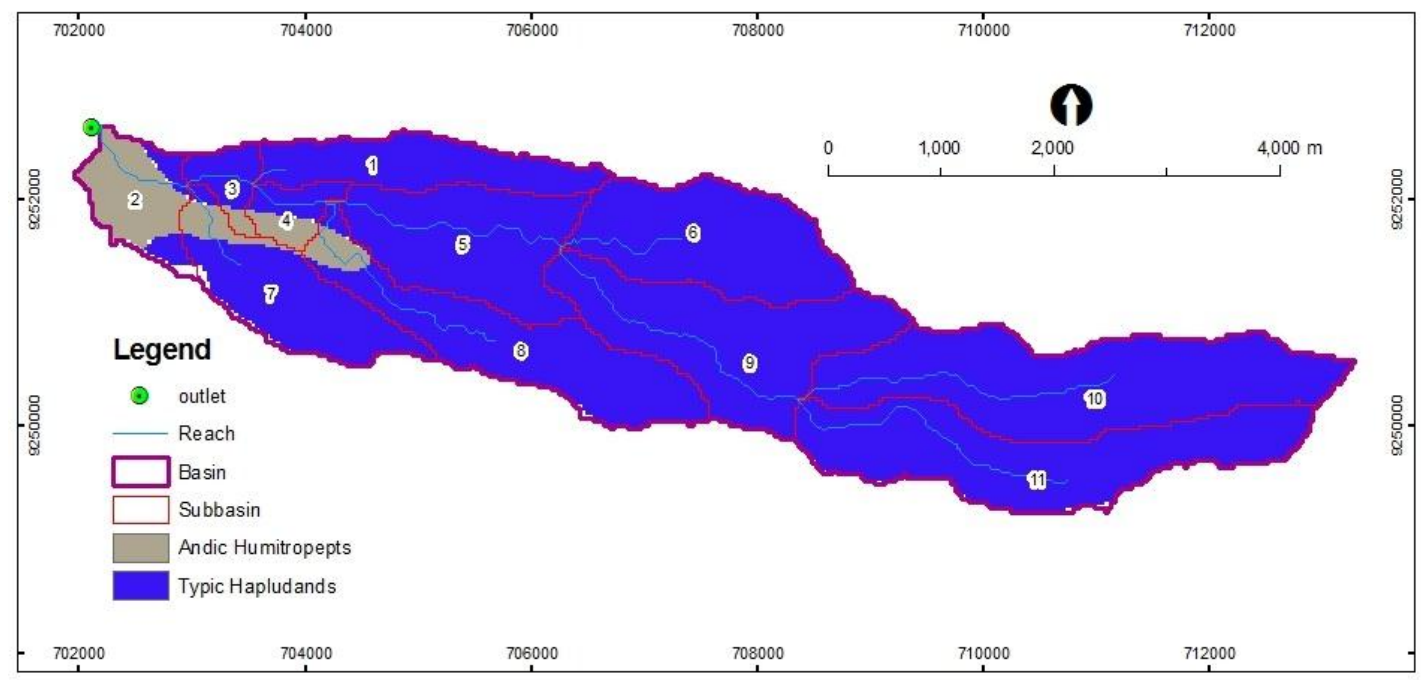

Gambar 2. Peta klasifikasi tanah berdasarkan model SWAT 
Tabel 3. Kelompok hidrologi, morfologi dan sifat-sifat tanah

\begin{tabular}{|c|c|c|c|c|c|c|c|}
\hline Deskripsi & Satuan & \multicolumn{3}{|c|}{ Andic Humitropepts } & \multicolumn{3}{|c|}{ Typic Hapludands } \\
\hline Jumlah Horison tanah & - & \multicolumn{3}{|c|}{3} & \multicolumn{3}{|c|}{3} \\
\hline Kelompok hidrologi tanah & - & \multicolumn{3}{|c|}{ B } & \multicolumn{3}{|c|}{ A } \\
\hline Kedalaman tanah & $\mathrm{mm}$ & \multicolumn{3}{|c|}{1200} & \multicolumn{3}{|c|}{1400} \\
\hline Lapisan Tanah ke- & & 1 & 2 & 3 & 1 & 2 & 3 \\
\hline Kedalaman lapisan tanah & $\mathrm{mm}$ & 200 & 400 & 600 & 300 & 500 & 600 \\
\hline Bobot isi tanah (Bulk Density) & $\mathrm{g} \mathrm{cm}^{-3}$ & 0.8 & 1.0 & 1.1 & 0.7 & 0.9 & 1.0 \\
\hline Kapasitas air tanah tersedia & $\mathrm{mm} \mathrm{mm}^{-1}$ & 0.1 & 0.1 & 0.1 & 0.17 & 0.17 & 0.17 \\
\hline Kandungan bahan organik & $\%$ & 4.5 & 3.2 & 3.0 & 2.7 & 2.1 & 2.0 \\
\hline Konduktivitas hidrolik & $\mathrm{mm} \mathrm{jam}^{-1}$ & 26.2 & 26.2 & 26.2 & 29.7 & 29.7 & 29.7 \\
\hline Kandungan liat & $\%$ & 16 & 16 & 16 & 16 & 14 & 13 \\
\hline Kandungan debu & $\%$ & 21 & 21 & 21 & 21 & 18 & 17 \\
\hline Kandungan pasir & $\%$ & 53 & 53 & 53 & 58 & 56 & 55 \\
\hline Kandungan batu & $\%$ & 10 & 10 & 10 & 5 & 12 & 15 \\
\hline Albedo tanah & Fraksi & 0.21 & 0.22 & 0.23 & 0.21 & 0.22 & 0.23 \\
\hline Nilai erodibilitas tanah (USLE-K) & - & 0.32 & 0.28 & 0.27 & 0.28 & 0.26 & 0.24 \\
\hline
\end{tabular}

\section{Tutupan Lahan}

Berdasarkan interpretasi citra satelit, tutupan lahan di Sub DAS Lengkong digolongkan dalam tujuh kelas pada model SWAT yaitu: (1) ladang, (2) petanian lahan kering campuran, (3) hutan, (4) semak belukar, (5) padang rumput, (6) sawah, dan (7) pemukiman dengan nilai $\mathrm{CN}$ tertinggi 92 untuk pemukiman dan C-USLE tertinggi 0.2 untuk ladang (Tabel 4).

Tutupan lahan hutan berada di bagian paling hulu dengan luas mencapai $58.7 \%$ dari luas Sub DAS Lengkong (Gambar 3). Di bagian hilir Sub DAS Lengkong didominasi oleh tutupan lahan ladang sedangkan di bagian tengah DAS didominasi oleh tutupan lahan semak belukar 468 ha dan pertanian campuran 107 ha.

Tabel 4. Hasil identifikasi tutupan lahan berdasarkan model SWAT

\begin{tabular}{|c|c|c|c|c|c|}
\hline Tutupan lahan & Kode SWAT & Luas (ha) & Luas (\%) & Nilai $\mathrm{CN}^{*}$ ) & C-USLE \\
\hline Ladang & AGRL & 87 & 4.85 & 77 & 0.200 \\
\hline Pertanian campuran & AGRC & 107 & 6.00 & 73 & 0.030 \\
\hline Hutan & FRSE & 1050 & 58.70 & 55 & 0.001 \\
\hline Semak belukar & FRST & 469 & 26.25 & 60 & 0.010 \\
\hline Padang rumput & PAST & 3 & 0.15 & 69 & 0.030 \\
\hline Sawah & RICE & 61 & 3.42 & 73 & 0.030 \\
\hline Pemukiman & URML & 11 & 0.64 & 92 & - \\
\hline & - & 1788 & 100.00 & - & - \\
\hline
\end{tabular}

*) pada kelompok hidrologi tanah B, Sumber: Neitsch et al. (2005)

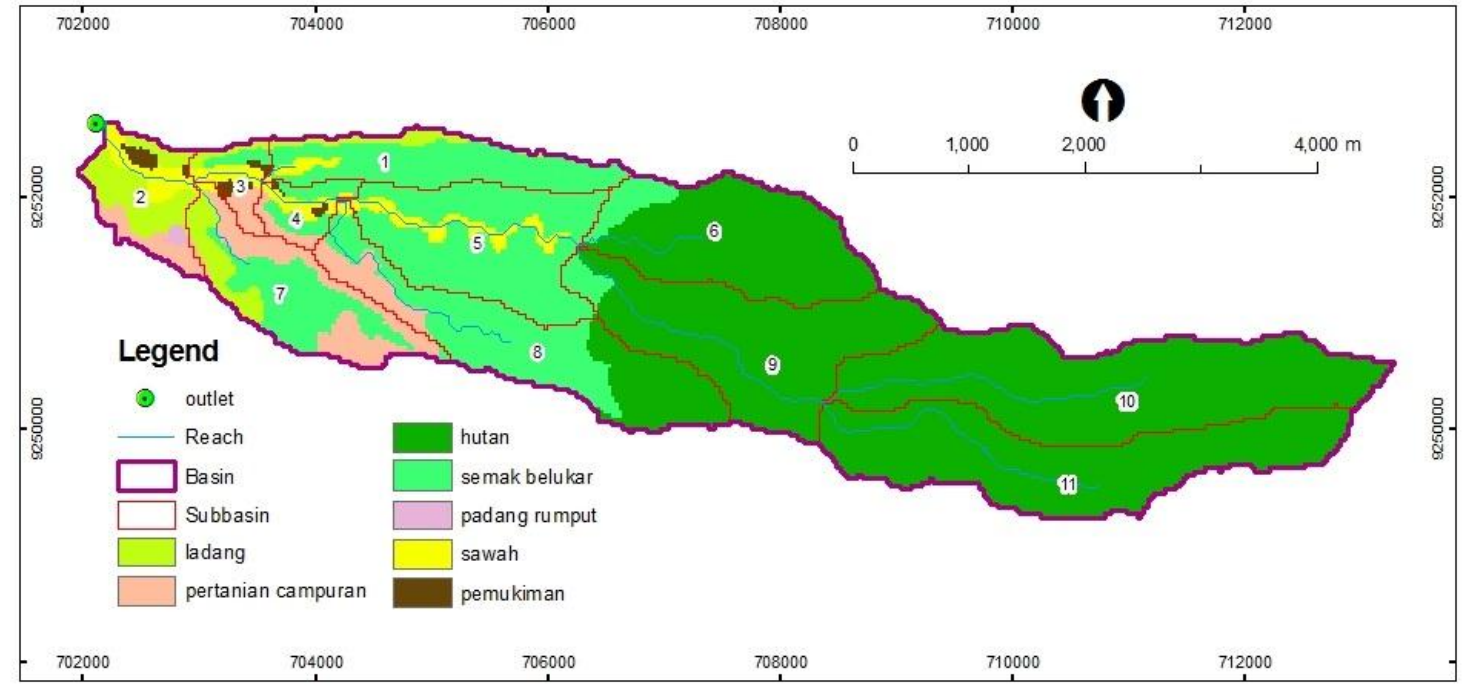

Gambar 3. Peta klasifikasi tutupan lahan berdasarkan model SWAT 


\section{Kelas Kelerengan}

Berdasarkan hasil model SWAT, kelas kelerengan Sub DAS Lengkong didominasi oleh lereng sangat curam (>40\%) seluas 1,110 ha (63\%) khas daerah hulu DAS dan kelas kelerengan tersempit adalah landai $(0-8 \%)$ seluas 17 ha (Tabel 5). Lereng yang sangat curam dan curam berada di bagian hulu DAS (Gambar 4).

Tabel 5. Hasil identifikasi kelas kelerengan model SWAT

\begin{tabular}{llrr}
\hline Slope $(\%)$ & Definisi & Luas (ha) & Luas (\%) \\
\hline $0-8$ & Landai & 17 & 0.93 \\
$8-15$ & Bergelombang & 55 & 3.06 \\
$15-25$ & Berbukit & 185 & 10.36 \\
$25-40$ & Curam & 422 & 23.60 \\
$>40$ & Sangat Curam & 1,110 & 62.50 \\
\hline Jumlah: & - & 1,788 & 100.00 \\
\hline
\end{tabular}

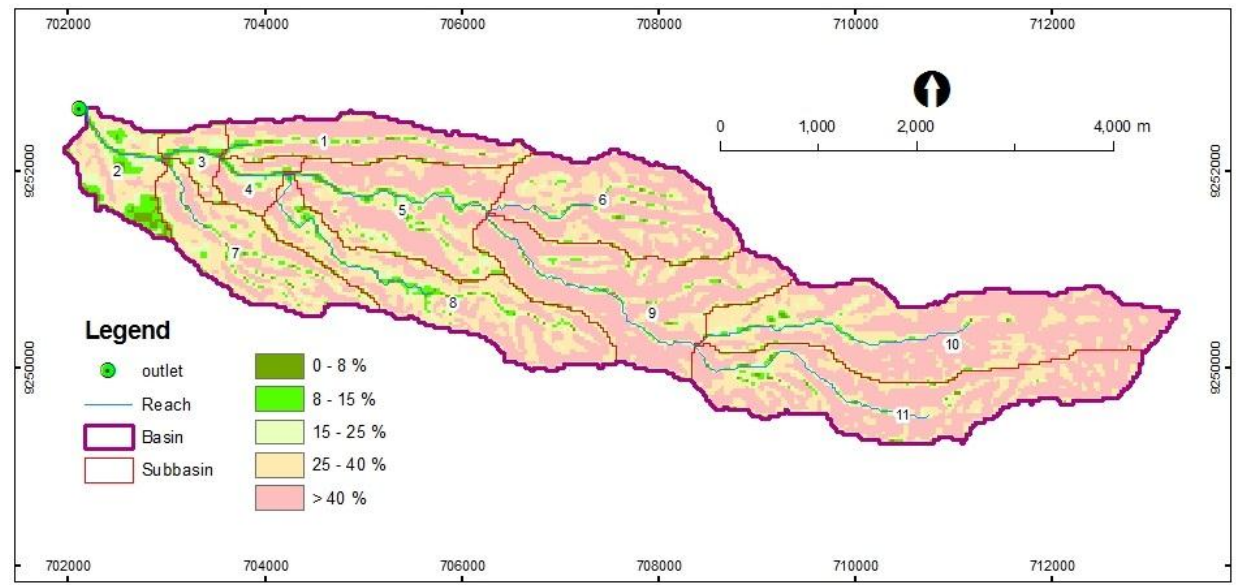

Gambar 4. Peta klasifikasi lereng berdasarkan model SWAT

\section{Uji Akurasi Model, Kalibrasi dan Validasi}

Hasil pengujian akurasi debit model sebelum kalibrasi terhadap debit hasil observasi lapangan selama 3 tahun (2009 - 2011) dengan menggunakan SWATPlot diperoleh $\mathrm{R}^{2}$ sebesar 0.46 dan NS sebesar 0.41 , sedangkan pengujian terhadap hasil sedimen model awal sebelum kalibrasi diperoleh $\mathrm{R}^{2}$ dan NS masing-masing 0.42 dan 0.39 .

Tabel 6. Nilai kalibrasi menggunakan model SWAT-CUP

\begin{tabular}{|c|c|c|c|c|c|}
\hline \multirow[t]{2}{*}{ No } & \multirow[t]{2}{*}{ Parameter *) } & \multirow{2}{*}{$\begin{array}{c}\text { Nilai input } \\
\text { awal }\end{array}$} & \multicolumn{3}{|c|}{ Nilai hasil kalibrasi } \\
\hline & & & Fitted_value & Min_value & Max_value \\
\hline 2 & v_ALPHA_BF.gw & 0.05 & 0.20 & 0.10 & 1.00 \\
\hline 4 & v_GWQMN.gw & $2,500.00$ & $1,122.50$ & 0.00 & $5,000.00$ \\
\hline 5 & v__GW_REVAP.gw & 0.02 & 0.01 & 0.00 & 0.20 \\
\hline 6 & v_ESCO.hru & 0.95 & 0.96 & 0.01 & 1.00 \\
\hline 9 & v_ALPHA_BNK.rte & 0.00 & 0.02 & 0.00 & 1.00 \\
\hline 10 & r_SOL_AWC(1).sol & 1.00 & 0.12 & -0.20 & 0.40 \\
\hline 11 & r__SOL_K(1).sol & 1.00 & -0.30 & -0.80 & 0.80 \\
\hline 12 & r_SOL_BD(1).sol & 1.00 & 0.33 & -0.50 & 0.60 \\
\hline 13 & v_RCHRG_DP.gw & 0.00 & 0.36 & 0.00 & 1.00 \\
\hline 18 & v_SHALLST.gw & 400.00 & 556.50 & 0.00 & $1,000.00$ \\
\hline 19 & v_DEEPST.gw & $1,000.00$ & $2,197.50$ & 0.00 & $3,000.00$ \\
\hline 20 & v_GW_SPYLD.gw & 0.03 .00 & 0.12 & 0.00 & 0.40 \\
\hline 21 & r_SOL_ZMX.sol & 1.00 & -0.15 & -0.20 & 0.40 \\
\hline 22 & r_SOL_CRK.sol & 1.00 & 0.14 & -0.20 & 0.40 \\
\hline 23 & r__SLSUBBSN.hru & 1.00 & -0.09 & -0.20 & 0.40 \\
\hline 24 & r_HRU_SLP.hru & 1.00 & 0.37 & -0.20 & 0.40 \\
\hline 25 & r_oV_N.hru & 1.00 & -0.08 & -0.20 & 0.40 \\
\hline 26 & r_LAT__TTIME.hru & 1.00 & -0.07 & -0.20 & 0.40 \\
\hline 27 & r_LAT_SED.hru & 1.00 & -0.10 & -0.20 & 0.40 \\
\hline 28 & r_SLSOIL.hru & 1.00 & 0.22 & -0.20 & 0.40 \\
\hline
\end{tabular}


Kalibrasi dilakukan dengan menggunakan SWATCUP terhadap debit dan sedimen model selama periode 3 tahun (2009 - 2011) sebanyak 1095 data debit dan sedimen $(n=1095)$ dengan iterasi yang dilakukan sebanyak 1000 simulasi. Hasil kalibrasi diperoleh nilai terbaik (fitted_value) untuk masing-masing parameter input yang digunakan untuk menggantikan nilai awal (Tabel 6). Hasil uji keakuratan debit hasil validasi model tahun 2011 pada SWATPlot $\mathrm{R}^{2}$ sebesar 0.86 dan NS sebesar 0.85 . Hasil uji keakuratan sedimen hasil validasi model berdasarkan SWATPlot, $\mathrm{R}^{2}$ sebesar 0.85 dan NS sebesar 0.76. Dengan demikian model sudah dapat digunakan untuk melakukan penerapan skenario teknik konservasi tanah.

\section{Respon Hidrologi terhadap Kondisi Biofisik}

Hasil analisis pada model SWAT menunjukkan bahwa pemukiman memiliki tebal aliran permukaan sebesar 2,314.32 mm pada tahun 2011, diikuti dengan tutupan lahan sawah sebesar 1,530.01 mm, ladang sebesar $1,034.10 \mathrm{~mm}$, pertanian campuran sebesar $686.40 \mathrm{~mm}$, semak belukar sebesar $597.92 \mathrm{~mm}$ padang rumput sebesar $344.23 \mathrm{~mm}$, dan hutan sebesar $176.35 \mathrm{~mm}$. Angka ini menunjukkan bahwa infiltrasi yang terjadi pada pemukiman dan sawah nilainya kecil karena pemukiman didominasi oleh areal yang kedap air dan sawah memiliki mulsa air yang juga kedap air, sehingga pada kedua tipe tutupan lahan ini aliran permukaan menjadi tinggi. Berdasarkan tebal curah hujan tahun 2011 sebesar 3,447 $\mathrm{mm}$, maka koefisien aliran untuk masing-masing penutupan lahan berturut-turut mulai dari nilai yang tertinggi yaitu pemukiman sebesar 0.67; sawah sebesar 0.44; ladang sebesar 0.30; pertanian campuran sebesar 0.20 ; semak belukar sebesar 0.17 ; padang rumput sebesar 0.10 dan hutan sebesar 0.05 .

Untuk nilai erosi yang ditimbulkan pada masingmasing tutupan lahan, hasil analisis model SWAT menunjukkan bahwa ladang menghasilkan erosi sebesar 263.91 ton $\mathrm{ha}^{-1}$ pada tahun 2011, diikuti dengan pertanian campuran sebesar 165.23 ton ha $^{-1}$, pemukiman sebesar 89.42 ton ha $^{-1}$, sawah sebesar 35.9 ton ha ${ }^{-1}$, semak belukar

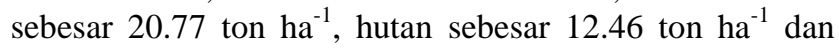

padang rumput sebesar 7.08 ton $\mathrm{ha}^{-1}$. Ladang dan pertanian campuran mempunyai nilai erosi yang tinggi karena adanya pengolahan tanah pada musim tanam yang dilakukan pada musim hujan.

\section{Respon Hidrologi terhadap Skenario Konservasi Tanah}

\section{Fluktuasi Debit Aliran}

Hasil perhitungan KRS untuk 5 skenario teknik konservasi tanah yang diterapkan beruturut-turut dari mulai yang nilainya kecil adalah skenario 5 sebesar 149.31, skenario 1 dan skenario 2 sebesar 149.71, skenario 3 sebesar 149.80 dan skenario 4 sebesar 150.25 (Tabel 7).

Tabel 7. KRS pada beberapa skenario teknik konservasi tanah

\begin{tabular}{lccc}
\hline \multicolumn{1}{c}{ Skenario } & $\begin{array}{c}\text { Qmak } \\
\left(\mathrm{m}^{3} \text { detik }^{-1}\right)\end{array}$ & $\begin{array}{c}\text { Qmin } \\
\left(\mathrm{m}^{3} \text { detik }^{-1}\right)\end{array}$ & $\begin{array}{c}\text { KRS } \\
(\text { Qmak/Qmin })\end{array}$ \\
\hline 0. tanpa skenario & 15.42 & 0.10 & 152.82 \\
1. strip cropping & 15.24 & 0.10 & 149.71 \\
2. contour & 15.24 & 0.10 & 149.71 \\
cropping & 15.25 & 0.10 & 149.80 \\
3. terracing & 15.28 & 0.10 & 150.25 \\
4. $(1+2)$ & 15.23 & 0.10 & 149.31 \\
5. $(1+2+3)$ & rata-rata harian minimum. & \\
\hline Keterangan : Qmak = debit rata-rata harian maksimum dan Qmin $=$ debit
\end{tabular}

\section{Indeks Bahaya Erosi}

Berdasarkan perbandingan antara erosi potensial dengan erosi yang dapat ditoleransi (TSL), diperoleh indeks bahaya erosi (Tabel 8) untuk skenario1, 2, 3, 4 dan 5 berturut-turut adalah 2.63 (sedang), 2.57 (sedang), 0.60 (rendah), 2.45 (sedang) dan 0.44 (rendah). Untuk perhitungan indeks bahaya erosi ini, nilai TSL adalah 32.2 ton ha tahun ${ }^{-1}$ berdasarkan kedalaman solum tanah 1,400 $\mathrm{mm}$, nilai faktor kedalaman tanah 0.8 dan umur guna tanah 400 tahun (Arsyad, 2010) serta bobot isi tanah $1.15 \mathrm{~g} \mathrm{~cm}^{-3}$.

Tabel 8. Indeks bahaya erosi pada lima skenario konservasi tanah

\begin{tabular}{lcccc}
\hline \multicolumn{1}{c}{ Skenario } & $\begin{array}{c}\text { Erosi potensial } \\
\left(\text { ton }^{-1} \text { tahun }^{-1}\right)\end{array}$ & $\begin{array}{c}\text { Erosi yang dapat } \\
\text { ditoleransi } \\
\left.\text { ton ha }^{-1} \text { tahun }^{-1}\right)\end{array}$ & $\begin{array}{c}\text { Indeks Bahaya } \\
\text { Erosi }\end{array}$ & Kategori \\
\hline 0. tanpa skenario & 129.07 & 32.2 & 4.01 & Tinggi \\
1. strip cropping & 84.78 & 32.2 & 2.63 & Sedang \\
2. contour cropping & 82.83 & 32.2 & 2.57 & Sedang \\
3. terracing & 19.32 & 32.2 & 0.60 & Rendah \\
4. $(1+2)$ & 79.01 & 32.2 & 2.45 & Sedang \\
5. $(1+2+3)$ & 14.29 & 32.2 & 0.44 & Rendah \\
\hline
\end{tabular}

\section{SIMPULAN}

Hasil analisis respon hidrologi terhadap kondisi biofisik DAS menunjukkan bahwa tutupan lahan pemukiman dan sawah mempunyai tebal aliran permukaan lebih tinggi dibandingkan dengan tutupan lahan lainnya. Hal ini disebabkan pemukiman mempunyai areal kedap air yang menghambat terjadinya proses infiltrasi. Adapun pada sawah, tebal aliran permukaan yang tinggi disebabkan oleh adanya lapisan tapak bajak yang menghambat proses infiltrasi. Erosi yang ditimbulkan untuk masing-masing tutupan lahan, menunjukkan bahwa ladang dan pertanian campuran mempunyai erosi lebih tinggi dibandingkan tutupan lahan lainnya. Hal ini disebabkan adanya kegiatan pengolahan tanah pada musim tanam yang dilakukan sewaktu musim hujan.

Hasil analisis respon hidrologi terhadap penerapan skenario teknik konservasi tanah menunjukkan bahwa 
skenario teknik konservasi tanah yang mengkombinasikan penanaman tanaman strip, penanaman pohon mengikuti kontur dan pembuatan teras secara bersamaan merupakan konservasi tanah terbaik dengan KRS dan indek bahaya erosi yang lebih rendah dibandingkan dengan skenario lainnya. Penerapan teknik konservasi tanah yang mengkombinasikan penanaman pohon mengikuti kontur, dan penanaman tanaman strip dengan pembuatan teras secara bersamaan, merupakan teknik konservasi tanah yang paling baik untuk memperbaiki respon hidrologi DAS yaitu kondisi fluktuasi debit yang lebih stabil dan sedimen yang lebih menurun, sehingga dapat direkomendasikan untuk dapat diterapkan di Sub DAS Lengkong pada khususnya dan di DAS Cisadane bagian hulu pada umumnya.

\section{DAFTAR PUSTAKA}

Abbaspour, K.C. 2011. SWAT-CUP4: SWAT Calibration And Uncertainty Programs - User Manual. Eawag: Swiss Federal Institute of Aquatic Science and Technology. Swiss.

Arsyad, S. 2010. Konservasi Tanah dan Air Edisi Kedua. IPB Press. Bogor.

Asdak, C. 2007. Hidrologi dan Pengelolaan Daerah Aliran Sungai. Gajah Mada University Press. Yogyakarta.
[BPDASCTW] Balai Pengelolaan Daerah Aliran Sungai Citarum-Ciliwung. 2012. Rencana Tindak Pengelolaan DAS Cisadane. Bogor.

[Kemenhut] Kementerian Kehutanan Republik Indonesia, 2009. Keputusan Menteri Kehutanan Republik Indonesia Nomor: SK.328/Menhut-II/2009 tentang Penetapan Daerah Aliran Sungai DAS Prioritas Dalam Rangka Rencana Pembangunan Jangka Menengah (RPJM) Tahun 2010-1014. Jakarta.

Latifah, I. 2013. Analisis ketersediaan air, sedimentasi, dan karbon organik dengan model SWAT di Hulu DAS Jeneberang, Sulawesi Selatan [Tesis]. IPB. Bogor.

Mulyana, N. 2012. Analisis luas tutupan hutan terhadap ketersediaan green water dan blue water di Sub DAS Gumbasa dan Sub DAS Cisadane Hulu dengan aplikasi model SWAT [Disertasi]. IPB. Bogor.

Nash, J.E. and J.V. Sutcliffe. 1970. River flow forecasting through conceptual models part I - discussion of principles. Journal of Hydrology, 10: 282-190.

Neitsch, S.L., J.G. Arnold, J.R. Kiniry, J.R. Williams, and K.W. King. 2005. Soil and Water Assessment Tool: Theoritical Documentation Version 2005. Texas.

Yustika, R.D. 2013. Pengelolaan lahan terbaik hasil simulasi model SWAT untuk mengurangi aliran permukaan di Sub DAS Ciliwung Hulu [Tesis]. IPB. Bogor. 